\title{
READINESS OF THE STUDENT- ATHLETE TO THE NEW NORMAL SPORTS COMPETITION
}

\author{
Ray-Ann H. Penus \\ Graduate School, Laguna State Polytechnic University, Santa Cruz, Laguna, Philippines
}

Article DOI: https://doi.org/10.36713/epra7472

DOI No: 10.36713/epra7472

\begin{abstract}
This study determined readiness of the Student - Athlete to the new normal sports competition to the Students-Athlete of Cavite State University specifically the basketball and volleyball players men and women, the study sought answers to the following questions: What is the demographic profile of the student-athlete in terms of; age;sex; gender; socioeconomic status; course intrams; regional; national? What is the extend of the readiness of the students-athletes in the sports competition in terms of: Innovative training approach; Safety precautionary measures? What is the level of the sports motivation of the student athletes in terms of; cooperation; work independent task competition; positive aggression? Is the Student-Athlete profile having a significant effect in the sports competition? Is the readiness of the student-athlete having a significant effect in the sports motivation?

In order to conduct this study, letters was sent to the University President Dr. Hernando D. Robles, asking permission and approval to conduct the study. Permission from the university Dean for each department. Preparation of self-made questionnaire by the researcher followed in order to obtain the necessary data on the readiness of the student-athletes it's effect to the new normal sports competition participated by the Cavite State University. The respondents of the study included were forty-eight (48) student-athletes specifically the basketball and volleyball players men and women category of the Cavite State University, Cavite City. The researcher-made questionnaire was checked by the thesis adviser and thesis consultant. The copies were multiples and others sent by the google form considering the health protocols. The main source of data which prepared by the researcher were statistically use a simple descriptive statistic such as T-test formula and the weighted mean to determine the mean level of readiness of the student-athletes to the new normal sports competition participated by the Cavite.
\end{abstract}

\section{INTRODUCTION}

Physical activity for children has been linked to positive self-esteem, skill development, skeletal and cardiovascular health, and general healthy development. It is now widely known that childhood is the best time to establish positive attitudes and behavior relating to physical activity and a healthy lifestyle. Young people spend a significant amount of time at school and therefore school environments need to be supportive of students being physically active. A challenge to everyone is facing the global crisis with the advent of COVID-19. The coronavirus disease 2019 (COVID-19) pandemic forced the world's population to alter daily routines, including exercise habits. This unusual situation has physical, psychological, and behavioral consequences to all individuals, including elite and recreational athletes. Life in lockdown has been difficult because everyone has to stay safe and healthy, while at the same time abiding by new norms. Currently, mitigation strategies have been widely implemented to contain the spread of COVID-19. These measures include lockdown, social distancing, personal protective measures, and environmental and surface cleaning, Nieman DC (2020). 


\section{SJIF Impact Factor 2021: 8.013| ISI I.F.Value:1.241| Journal DOI: 10.36713/epra2016 ISSN: 2455-7838(Online) EPRA International Journal of Research and Development (IJRD) Volume: 6 | Issue: 7 | July 2021 \\ - Peer Reviewed Journal}

Moreover, physical activity is necessary to the development of children as a whole, including their physical, social and emotional health. Sport should not be under-estimated because the benefits of it will reach beyond the impact on physical well-being and the value of the educational benefits.

Palmowski J. et. al. (2019) mentioned that the risk of opportunistic infection is more likely to be influenced by the pre-exercise physical, nutritional, and psychological well-being. It is known that regular and frequent exercise enhances rather than suppresses the immune response in individuals of all ages, and thus protects them from infections.

It is challenge to everyone to face the global crisis with the advent of COVID-19. There are many sacrificial events especially in the field of sports. It won't be easy for young players to return to their usual training, but there are other ways they must learn to adjust, prepare the physical, mental and even the emotional ability of the coaches and players in the new normal at the moment, that have currently.

Through this, the researcher seeks to study the readiness of the student-athlete to the new normal sports competition, how to bring back the eagerness of the athletes and coaches to get ready for the future competition in the new normal system.

\section{OBJECTIVES}

This study determined the readiness of the student - athlete the new normal sports competition. Specifically, the study sought answers to the following questions:

1.What is the status of profile of the Students-Athlete;

Age;

Sex;

Gender;

Socio-economic status;

Course

Intrams;

Regional;

National?

2. What is the level of readiness of the Students-Athlete in the new normal sports competition in terms of:

2.1 Innovative training approach;

2.2 Safety precautionary measures?

3. What is the level of the sports motivation of the student athletes in terms of;

3.1 Cooperation;

3.2 Positive aggression

3.3 Task competition;

3.4 Work independent?

4. Is there significance effect between the profile of the Student-Athlete and sports motivation?

5. There's significance effect between the readiness of the Student-Athlete in the new normal sports competition and sports motivation?

\section{METHODOLOGY}

Researcher consulted her statistician on the sampling techniques. Purposive sampling, also known as judgmental, selective, or subjective sampling, is a form of non-probability sampling in which researcher rely on their own judgment when choosing members of the population to participate in their study. This sampling method requires researchers to have prior knowledge about the purpose of their studies so that they can properly choose and approach eligible participants. Researchers use purposive sampling when they want to access a particular subset of people, as all participants of a study are selected because they fit a particular profile. Each individual was chosen entirely by chance and each member of the population has an equal chance of being included in the sample. The respondents of the study included were forty-eight (48) student-athletes specifically the basketball and volleyball players men and women category of the Cavite State University, Cavite City.

To meet the aim of to know the readiness of the student-athletes to the new normal sports competition participated by the Cavite State University. 


\section{SJIF Impact Factor 2021: 8.013| ISI I.F.Value:1.241| Journal DOI: 10.36713/epra2016 ISSN: 2455-7838(Online) EPRA International Journal of Research and Development (IJRD) Volume: 6 | Issue: 7 | July 2021 \\ - Peer Reviewed Journal}

The researcher is one of the Instructor of the said university. Purposive sampling technique was used to get the sample respondents Cavite State University in college level specifically the basketball and volleyball student-athlete. A validated researcher-made questionnaire was used as the major instrument to gather the adequate data and information from the respective subjects of the study.

The teacher questionnaire consisted of three parts; first part was about the demographic profile of the student-athletes in terms of: age, gender, year level, socio economic status, and course. Second part was about the readiness of the students-athletes in terms of: innovative training program and safety precautionary measures. Third part was sports competition participated by Cavite State University in terms of: Intramurals, Regional/STRASUC and National Level/ PASUC/ NCAA. The third part was the sports motivation of the student0athletes in terms of cooperation, work independence, task competition and positive aggression.

The respondents was asked to place a check mark on the responses they will choose from the given scale. A fivepoint rating scale was used to determine each part of the questionnaire. Each of the responses in the questionnaire was weighted as follows 5 with verbal interpretation of always or excellent; 4 with often or very satisfactory; 3 with sometimes or satisfactory; 2 with never or fair and 1 with never of poor.

In order to conduct this study, letters was sent to the University President Dr. Hernando D. Robles, asking permission and approval to conduct the study.

Permission from the university Dean for each department. Preparation of self-made questionnaire by the researcher followed in order to obtain the necessary data on the readiness of the student-athletes it's impact to the new normal sports competition participated by the Cavite State University,

The researcher-made questionnaire was checked by the thesis adviser. Face validation of the contents of the questionnaire was done by the adviser of the researcher and other panel members in the researchers list. They are vital panel members of the research department.

The copies of the questionnaire was multiplied based from the number of the respondents. Then it was administered. With confidentiality, the gathered information was transferred in a tally sheet. Subsequently, codes was assigned to each indicator. The encoded data was given to the researcher's statistician for the descriptive analysis. The gathered data was interpreted and presented in textual and tabular forms and appropriate interpretation was made.

The following statistical tools were used in order to analyze and interpret the gathered data:

Descriptive statistics will be going to apply to properly derive information and frequency distributions of the gathered data.

The answers of the respondents on the evaluation about the conducting study readiness of the student-athletes to the new normal sports competition participated by the Cavite State University is going to be analyze using the following formulas and measurements:

Weighted mean - used to find out the average responses of the respondents as measurement of the central tendency.

\section{RESULT AND DISCUSSION}

This chapter deals with the presentation, analysis and interpretation of data gathered to answer the sub problem relative to the main problem of this study on strategies on online distance learning on critical thinking and technical skills of the students. This part discusses the findings of the study based on the research questions. 


\section{DEMOGRAPHIC PROFILE OF THE STUDENT-ATHELETES}

Figure 1 below shows the data on the status of profile of the student-athletes in terms of Age.

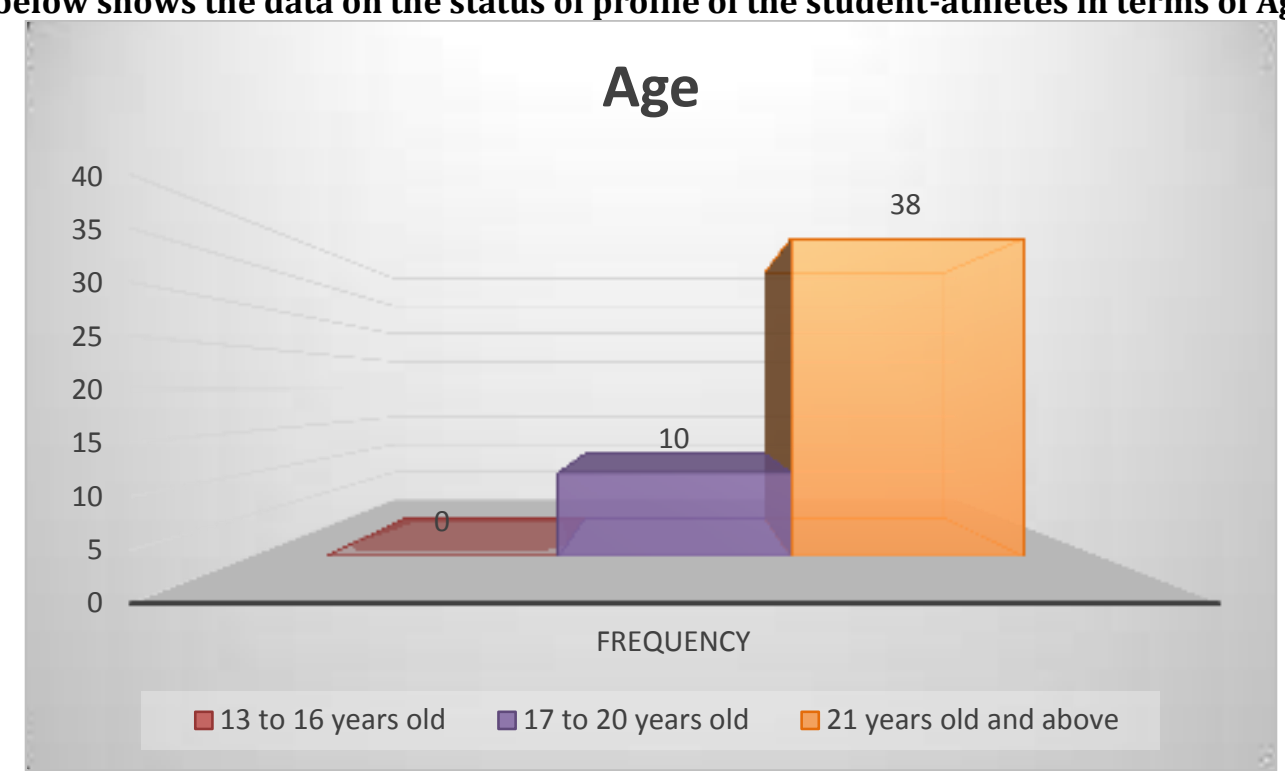

Graph shows that ages "21 years old and above" have the highest frequency of thirty-eight (38) or 79.17\% of the total respondent. And have ten (10) or $20.83 \%$ of the respondent are "17 to 19 years old". While the ages " 13 to 16 years old" received none $(0)$ or $0.00 \%$ of the total respondents.

Figure 2 shows the result data on the status of profile of the student-athletes in terms of Sex.

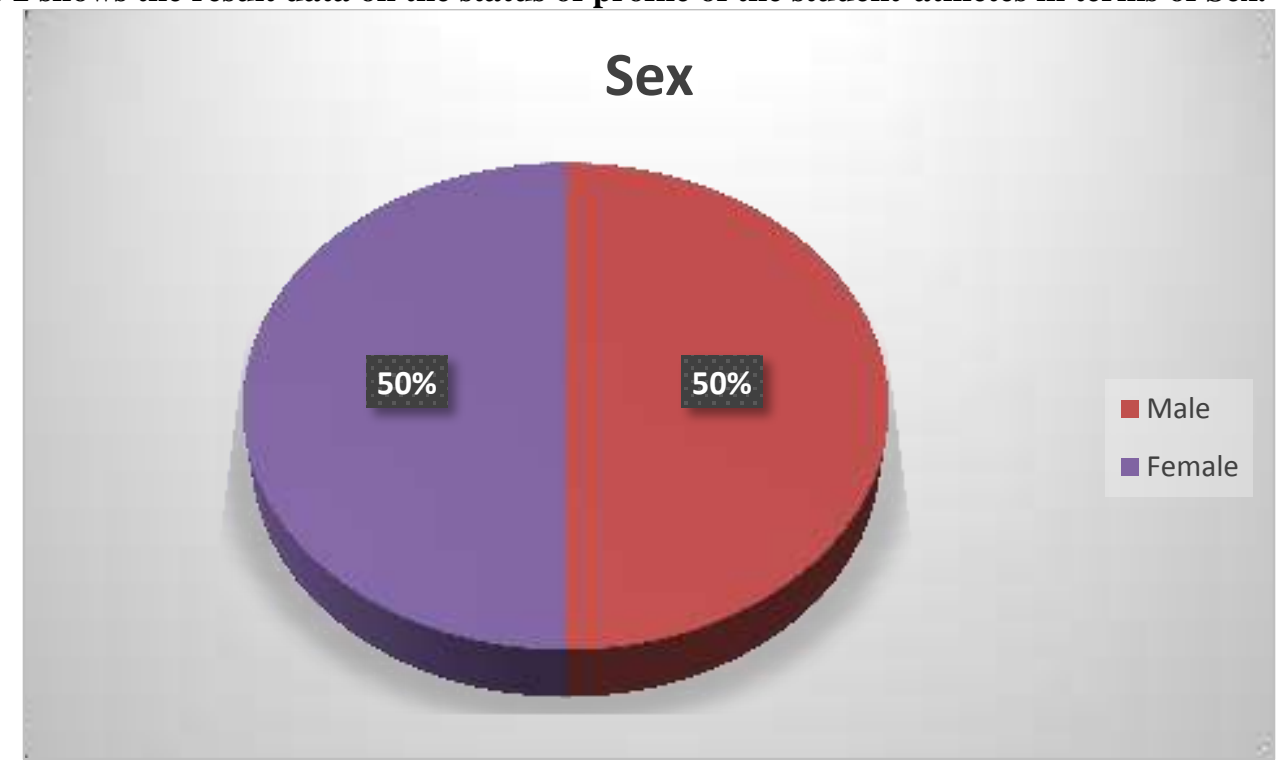

Graph shows that sex "Male and Female" have both the frequency of twenty-four (24) or $50.00 \%$ each of the total respondent. 
Figure 3 shows the data result on the status of profile of the student-athletes in terms of Gender.

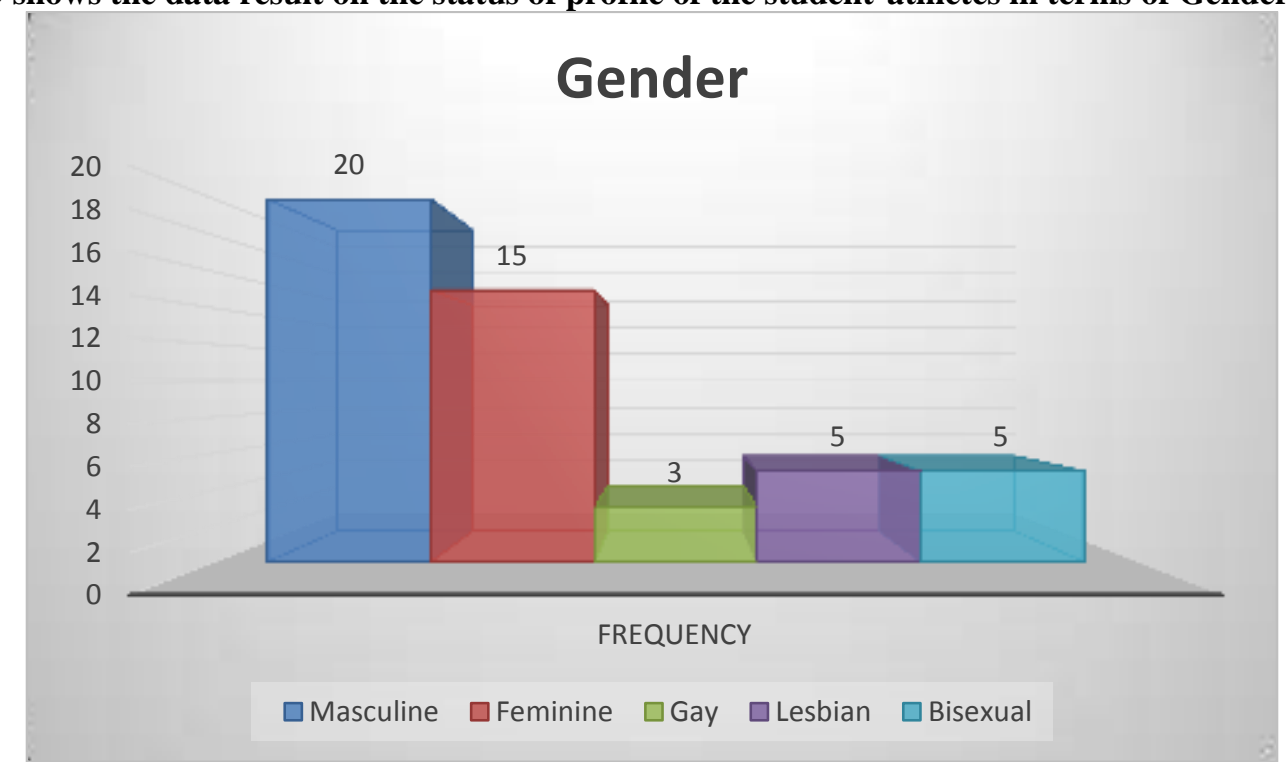

Graph shows that gender "Masculine" has the highest frequency of twenty (20) or $41.67 \%$ of the total respondent. And have fifteen (15) or $31.25 \%$ of the respondent are "Feminine". While the gender "Gay" received the lowest frequency of three (3) or $6.25 \%$ of the total respondents.

Figure 4 shows the result of the Status of profile of the student-athletes in terms of Monthly Family Income.

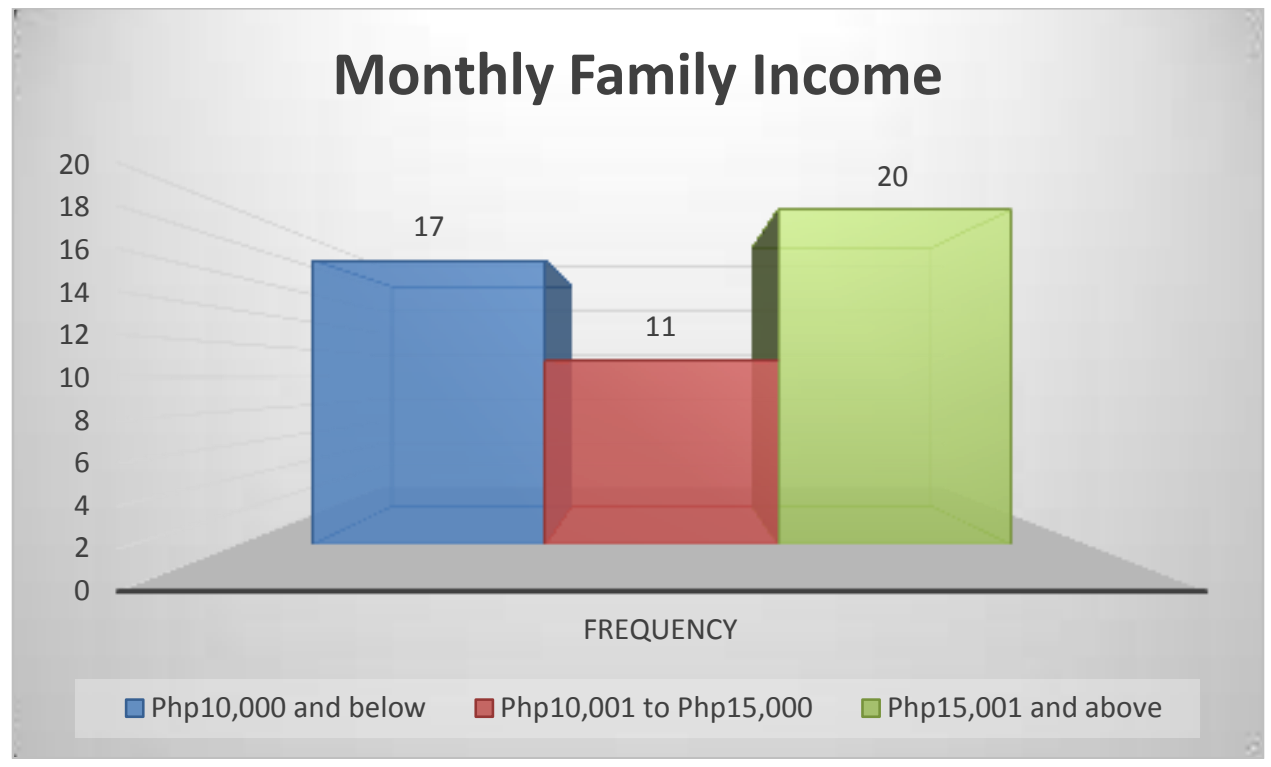

Graph shows that income "Php15,001 and above" have the highest frequency of twenty (20) or $41.67 \%$ of the total respondent. And have seventeen (17) or 35.42\% of the respondent are "Php10,000 and below". While the income "Php10,001 to Php15,000" received the lowest frequency of eleven (11) or $22.92 \%$ of the total respondents. 
Figure 5 shows the status of profile of the student-athletes in terms of Sports Competition.

\section{Sports Competition}

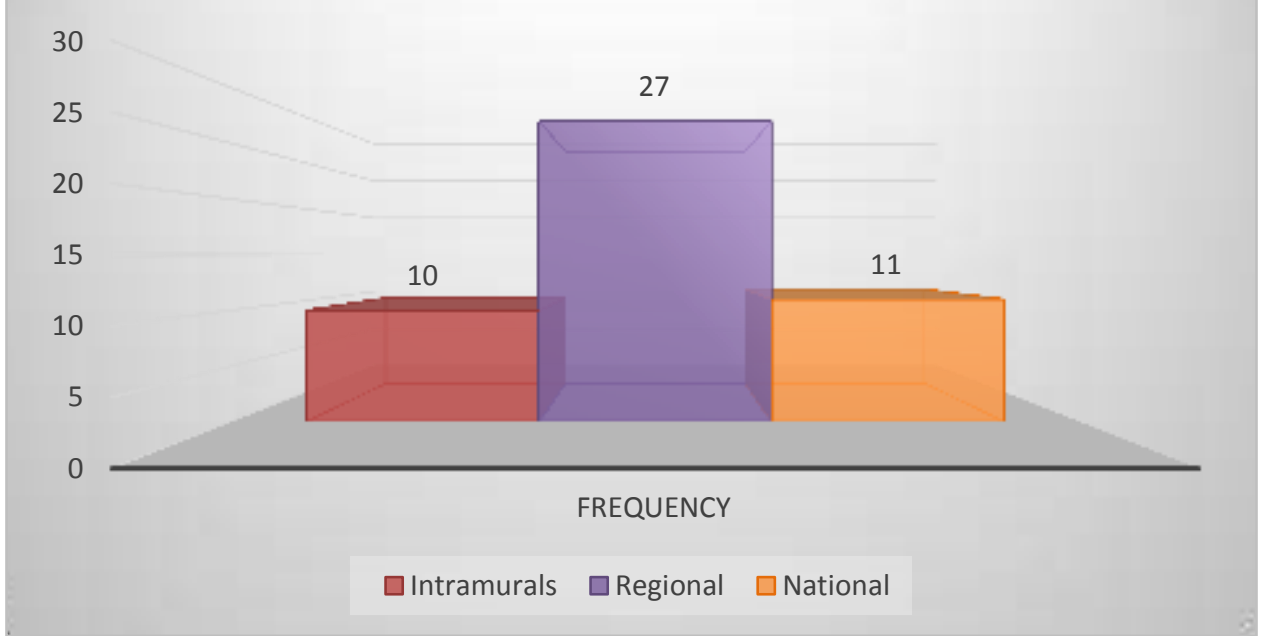

Graph shows that the competition "Regional" have the highest frequency of twenty-seven (27) or 56.25\% of the total respondent. And have eleven (11) or $22.92 \%$ of the respondent attended "National". While the competition "Intramurals" received the lowest frequency of ten (10) or $20.83 \%$ of the total respondents.

Table 1 Level of readiness of the student-athlete in the new normal sports competition in terms of Innovative Training Approach

\begin{tabular}{|l|l|l|l|}
\hline \multicolumn{1}{|c|}{ Statements } & Mean & SD & Remarks \\
\hline $\begin{array}{l}\text { Improve agility by performing the various agility tests and } \\
\text { by incorporating specific drills into your workouts like, } \\
\text { cutting drilling using cones, agility ladder drills, and short } \\
\text { circuit workouts with lateral movement are ways to } \\
\text { become more athlete. }\end{array}$ & 4.48 & 0.82 & Always \\
\hline $\begin{array}{l}\text { Stretch my body to become more supple and flexible } \\
\text { physical benefits by mean of such training allows for } \\
\text { easier and deeper movements while building strength and } \\
\text { stability. }\end{array}$ & 4.67 & 0.69 & Always \\
\hline $\begin{array}{l}\text { Stretching my muscles and joints also leads to greater } \\
\text { range of motion, improved balance, and } \\
\text { increased flexibility. }\end{array}$ & 4.63 & 0.61 & Always \\
\hline $\begin{array}{l}\text { Do strengthening exercise, or resistance training, good } \\
\text { for muscles by using resistance movement, like with the } \\
\text { use of a dumbbell or your own body weight such as push } \\
\text { ups. }\end{array}$ & 4.60 & 0.64 & Always \\
\hline $\begin{array}{l}\text { Do the cardio exercise to measure and maintain the } \\
\text { endurance in my respective discipline. }\end{array}$ & 4.58 & 0.68 & Always \\
\hline $\begin{array}{l}\text { Overall Mean = 4.58 } \\
\text { Verbal Interpretation = Very High }\end{array}$ & & \\
\hline
\end{tabular}


Table 2 below shows readiness of the student-athlete in the new normal sports competition in terms of Innovative Training Approach

Based on the respondents' perceptions, the level of the readiness of the student-athlete in the new normal sports competition in terms of Innovative Training Approach was generally very high. They stretch body to become more supple and flexible physical benefits by mean of such training allows for easier and deeper movements while building strength and stability have $(M=4.67, S D=0.69)$ and stretching muscles and joints also leads to greater range of motion, improved balance, and increased flexibility with $(M=4.63, S D=0.61)$.

Table 2. Level of readiness of the student-athlete in the new normal sports competition in terms of Safety Precautionary Measure

\begin{tabular}{|l|l|l|l|}
\hline \multicolumn{1}{|c|}{ Statements } & Mean & SD & Remarks \\
\hline Check the body temperature with the use of thermometer. & 4.33 & 0.78 & Always \\
\hline $\begin{array}{l}\text { Wear mask as one of the protocols to prevent the spread of } \\
\text { virus. }\end{array}$ & 4.69 & 0.72 & Always \\
\hline $\begin{array}{l}\text { Sanitized my hand with the use of alcohol and other } \\
\text { sanitizer. }\end{array}$ & 4.81 & 0.45 & Always \\
\hline $\begin{array}{l}\text { Make sure that all my teammates are in good condition } \\
\text { and free from any signs of sickness. }\end{array}$ & 4.81 & 0.39 & Always \\
\hline $\begin{array}{l}\text { Take a bath after the training to maintain the cleanliness } \\
\text { and prevent virus causing germs. }\end{array}$ & 4.79 & 0.46 & Always \\
\hline $\begin{array}{l}\text { Overall Mean }=\mathbf{4 . 7 9} \\
\text { Standard Deviation }=\mathbf{0 . 6 0 5} \\
\text { Verbal Interpretation }=\text { Very High }\end{array}$ & & \\
\hline
\end{tabular}

Table 2 below shows Level of readiness of the student-athlete in the new normal sports competition in terms of Safety Precautionary Measure. Based on the respondents' perceptions, the level of the readiness of the studentathlete in the new normal sports competition in terms of Safety Precautionary Measure was generally very high. They sanitized hand with the use of alcohol and other sanitizer and make sure that all the teammates are in good condition and free from any signs of sickness have $(M=4.81, S D=0.45,0.39)$ and take a bath after the training to maintain the cleanliness and prevent virus causing germs with $(M=4.79, S D=0.46)$.

Table 3. Level of sports motivation of the student-athlete in terms of Cooperation

\begin{tabular}{|l|l|l|l|}
\hline \multicolumn{1}{|c|}{ Statements } & Mean & SD & Remarks \\
\hline $\begin{array}{l}\text { Set a meeting to prepare a game plan and strategies for } \\
\text { the upcoming competition. }\end{array}$ & 4.56 & 0.54 & Always \\
\hline $\begin{array}{l}\text { Train and set some tune-up and friendly games as part of } \\
\text { the training. }\end{array}$ & 4.56 & 0.62 & Always \\
\hline $\begin{array}{l}\text { Set the mind and goals for clear and well performance for } \\
\text { the competition. }\end{array}$ & 4.81 & 0.49 & Always \\
\hline Stay focused and optimistic & 4.75 & 0.53 & Always \\
\hline $\begin{array}{l}\text { Build confidence and increased the chance of positive } \\
\text { performance outcomes. }\end{array}$ & 4.75 & 0.48 & Always \\
\hline $\begin{array}{l}\text { Overall Mean }=\mathbf{4 . 7 5} \\
\text { Standard Deviation }=\mathbf{0 . 5 3 9} \\
\text { Verbal Interpretation }=\text { Very High }\end{array}$ & & & \\
\hline
\end{tabular}

Table 3 shows Level of sports motivation of the student-athlete in terms of Cooperation. Based on the respondents' perceptions, the level of sports motivation of the student-athlete in terms of Cooperation was generally very high. They set the mind and goals for clear and well performance for the competition have $(M=4.81, S D=0.49)$ and stay focused and optimistic and build confidence and increased the chance of positive performance outcomes with $(M=4.75, S D=0.53,0.48)$. 
Table 4. Level of sports motivation of the student-athlete in terms of Cooperation

\begin{tabular}{|l|l|l|l|}
\hline \multicolumn{1}{|c|}{ Statements } & Mean & SD & Remarks \\
\hline $\begin{array}{l}\text { Set a meeting to prepare a game plan and strategies for } \\
\text { the upcoming competition. }\end{array}$ & 4.56 & 0.54 & Always \\
\hline $\begin{array}{l}\text { Train and set some tune-up and friendly games as part of } \\
\text { the training. }\end{array}$ & 4.56 & 0.62 & Always \\
\hline $\begin{array}{l}\text { Set the mind and goals for clear and well performance for } \\
\text { the competition. }\end{array}$ & 4.81 & 0.49 & Always \\
\hline Stay focused and optimistic & 4.75 & 0.53 & Always \\
\hline $\begin{array}{l}\text { Build confidence and increased the chance of positive } \\
\text { performance outcomes. }\end{array}$ & 4.75 & 0.48 & Always \\
\hline $\begin{array}{l}\text { Overall Mean }=\mathbf{4 . 7 5} \\
\text { Standard Deviation }=\mathbf{0 . 5 3 9} \\
\text { Verbal Interpretation }=\text { Very High }\end{array}$ & & & \\
\hline
\end{tabular}

Table 4 show Level of sports motivation of the student-athlete in terms of Cooperation. Based on the respondents' perceptions, the level of sports motivation of the student-athlete in terms of Cooperation was generally very high. They set the mind and goals for clear and well performance for the competition have $(\mathrm{M}=4.81, \mathrm{SD}=0.49)$ and stay focused and optimistic and build confidence and increased the chance of positive performance outcomes with $(\mathrm{M}=4.75, \mathrm{SD}=0.53,0.48)$.

Table 5. Level of sports motivation of the student-athlete in terms of Positive Aggression

\begin{tabular}{|l|l|l|l|}
\hline \multicolumn{1}{|c|}{ Statements } & Mean & SD & Remarks \\
\hline $\begin{array}{l}\text { Punishment to performers that are displaying hostile or } \\
\text { instrumental aggression within sport e.g. fines, bans, red } \\
\text { cards. }\end{array}$ & 4.50 & 0.68 & Always \\
\hline $\begin{array}{l}\text { Channel aggression into the performance, focusing on the } \\
\text { task. }\end{array}$ & 4.56 & 0.68 & Always \\
\hline $\begin{array}{l}\text { Praise for non-aggressive behavior provided by the } \\
\text { peers/coaches. }\end{array}$ & 4.67 & 0.60 & Always \\
\hline Updated rules implemented in the sports they are playing. & 4.67 & 0.56 & Always \\
\hline Fault that each co-player may do. & 4.79 & 0.54 & Always \\
\hline $\begin{array}{l}\text { Overall Mean }=\mathbf{4 . 7 9} \\
\text { Standard Deviation }=\mathbf{0 . 6 1 9} \\
\text { Verbal Interpretation }=\text { Very High }\end{array}$ & & & \\
\hline
\end{tabular}

Table 5 shows Level of sports motivation of the student-athlete in terms of Positive Aggression. It means the student-athletes perception in the sports motivation in terms of positive aggression was observed and implemented during the performance in the competition and even the training.

Table 6. Level of sports motivation of the student-athlete in terms of Task Competition

\begin{tabular}{|l|l|l|l|}
\hline \multicolumn{1}{|c|}{ Statements } & Mean & SD & Remarks \\
\hline $\begin{array}{l}\text { Take arrangement in competitions between two teams, } \\
\text { each with two players. }\end{array}$ & 4.60 & 0.71 & Always \\
\hline Easily determine the teams' performance. & 4.58 & 0.61 & Always \\
\hline Be responsible on the one task team. & 4.75 & 0.53 & Always \\
\hline $\begin{array}{l}\text { Perform tasks simultaneously or sequentially leading to } \\
\text { the same actions. }\end{array}$ & 4.69 & 0.51 & Always \\
\hline Depend on their comparative advantages in tasks. & 4.40 & 0.74 & Always \\
\hline $\begin{array}{l}\text { Overall Mean }=\mathbf{4 . 4 0} \\
\text { Standard Deviation }=\mathbf{0 . 6 3 2} \\
\text { Verbal Interpretation = Very High }\end{array}$ & & \\
\hline
\end{tabular}


Table 5 shows Level of sports motivation of the student-athlete in terms of Task Competition. Based on the respondents' perceptions, the level of sports motivation of the student-athlete in terms of Task Competition was generally very high. Being responsible on the one task team have $(M=4.75, S D=0.53)$ and perform tasks simultaneously or sequentially leading to the same actions with $(M=4.69, S D=0.51)$. They depend on their comparative advantages in tasks with $(M=4.40, S D=0.74)$;

Table 7. Level of sports motivation of the student-athlete in terms of Work Independent

\begin{tabular}{|l|l|l|l|}
\hline \multicolumn{1}{|c|}{ Statements } & Mean & SD & Remarks \\
\hline Take the initiative rather than wait to be told what to do; & 4.17 & 1.08 & Often \\
\hline $\begin{array}{l}\text { Do what is asked to the best of one's ability without the need } \\
\text { for external prodding }\end{array}$ & 4.46 & 0.71 & Always \\
\hline Work until the training is completed. & 4.56 & 0.62 & Always \\
\hline Learn to work at a pace is sustainable & 4.56 & 0.82 & Always \\
\hline $\begin{array}{l}\text { Take ownership of one's mistakes without looking for } \\
\text { excuses. }\end{array}$ & 4.31 & 0.97 & Always \\
\hline $\begin{array}{l}\text { Overall Mean }=\mathbf{4 . 3 1} \\
\text { Standard Deviation }=\mathbf{0 . 8 6 3} \\
\text { Verbal Interpretation = Very High }\end{array}$ & & & \\
\hline
\end{tabular}

Table 7 shows Level of sports motivation of the student-athlete in terms of Work Independent. It means the level of sports motivation of the student athletes in terms of work independent was evident.

Table 8. Significant effect of the profile of the student-athlete to the sports motivation

\begin{tabular}{lllll}
\hline Age & Beta & t-value & p-value & Analysis \\
\hline Cooperation & 1.234 & 1.473 & 0.148 & Not Significant \\
Positive aggression & 0.229 & 0.558 & 0.579 & Not Significant \\
Task competition & -0.263 & -0.475 & 0.637 & Not Significant \\
Work independent & -0.879 & -1.823 & 0.075 & Not Significant \\
\hline Sex & & & & \\
\hline Cooperation & 3.154 & 5.244 & 0.000 & Significant \\
Positive aggression & 0.584 & 1.987 & 0.053 & Not Significant \\
Task competition & -0.672 & -1.690 & 0.098 & Not Significant \\
Work independent & -2.245 & -6.490 & 0.000 & Significant \\
\hline Gender & & & & \\
\hline Cooperation & 1.677 & 1.251 & 0.218 & Not Significant \\
Positive aggression & -1.623 & -2.475 & 0.017 & Significant \\
Task competition & -0.624 & -0.703 & 0.486 & Not Significant \\
Work independent & -1.008 & -1.307 & 0.198 & Not Significant \\
\hline Monthly Income & & & & \\
\hline Cooperation & 4.550 & 4.123 & 0.000 & Significant \\
Positive aggression & 0.919 & 1.703 & 0.096 & Not Significant \\
Task competition & -1.183 & -1.622 & 0.112 & Not Significant \\
Work independent & -3.314 & -5.221 & 0.000 & Significant \\
\hline Sports Event & & & & \\
\hline Cooperation & 1.244 & 1.281 & 0.207 & Not Significant \\
Positive aggression & -0.171 & -0.359 & 0.721 & Not Significant \\
Task competition & -0.434 & -0.676 & 0.503 & Not Significant \\
Work independent & -0.957 & -1.713 & 0.094 & Not Significant \\
\hline R-Square: 0.7209 & & & &
\end{tabular}

Adjusted R-Square: 0.7209

F-value:

122.39

Sig.:

0.0000 


\section{SJIF Impact Factor 2021: 8.013| ISI I.F.Value:1.241| Journal DOI: 10.36713/epra2016 \\ ISSN: 2455-7838(Online) \\ EPRA International Journal of Research and Development (IJRD) \\ Volume: 6 | Issue: 7 | July 2021 \\ - Peer Reviewed Journal}

Table 8 below shows revealed that Sports Motivation had no effect on profile of the student-athlete. The beta coefficient indicates that for every standard deviation unit increase in Cooperation, Positive Aggression, Task competition and Work independent, there is a corresponding unit increase in the profile of the student-athlete. The tvalue of Cooperation, Positive Aggression, Task competition and Work independent is not significant having a pvalue of greater than 0.05 level of significance.

Table 9. Significant effect of readiness of the student-athlete to the sports motivation

\begin{tabular}{lllll}
\hline Innovative Training Approach & Beta & t-value & p-value & Analysis \\
\hline Cooperation & -0.031 & -0.126 & 0.901 & Not Significant \\
Positive aggression & 0.852 & 7.058 & 0.000 & Significant \\
Task competition & 0.337 & 2.067 & 0.045 & Significant \\
Work independent & -0.009 & -0.066 & 0.948 & Not Significant \\
\hline Safety Precautionary Measures & & & & \\
\hline$\quad$ Cooperation & 1.048 & 3.048 & 0.004 & Significant \\
Positive aggression & -0.162 & -0.964 & 0.340 & Not Significant \\
Task competition & 0.006 & 0.027 & 0.979 & Not Significant \\
Work independent & 0.100 & 0.508 & 0.614 & Not Significant \\
\hline
\end{tabular}

Adjusted R-Square: 0.98 .07

F-value: $\quad 2391.7$

Sig.: $\quad 0.0000$

Table 9 shows Significant effect of readiness of the student-athlete to the sports motivation. Based on the data, it is shown that there is "no significant effect of the readiness of the student-athlete to the sports motivation" at 0.05 level of significance. It shows that the null hypothesis stating that "There is no significant effect of the readiness of the student-athlete to the sports motivation" is accepted, it can inferred that there is "no significant" effect between them.

\section{CONCLUSIONS}

Drawn the results of the study, the following results are set forth;

1. The null hypothesis stating that "There is no significant effect of the profile of the student-athlete to the sports motivation" is accepted, it can inferred that there is "no significant" effect between them.

2. The null hypothesis stating that "There is no significant effect of the readiness of the student-athlete to the sports motivation" is accepted, it can inferred that there is "no significant" effect between them.

\section{RECOMMENDATIONS}

In the light of the findings and conclusion of the study, the following recommendations were drawn.

1. The student-athletes may give importance to keep them motivated goals in achieving their desire level of completion despite of pandemic.

2. The student-athletes may continue to have focus on the trainings even in times of pandemic experiencing by them. Reaching goals may continue to pursue for the benefits of their future.

3. They may continue the habit that they have started to maintain the strength and ability to compete.

4. The Teacher-Coach may also communicate to the Student-Athletes to train and monitor the progress of the players in the observance of health protocols.

5. A follow-up, study may be conducted on the readiness of the Student-Athletes in the new normal sports competition. so, to assess the progress and development of the program. 


\section{SJIF Impact Factor 2021: 8.013| ISI I.F.Value:1.241| Journal DOI: 10.36713/epra2016 ISSN: 2455-7838(Online) EPRA International Journal of Research and Development (IJRD) Volume: 6 | Issue: 7 | July 2021 - Peer Reviewed Journal}

\section{REFERENCES}

1. Akar, E. O. (2012). Motivations of Turkish pre-service teachers to choose teaching as a career. Australian Journal of Teacher Education, 37(10), 67-84.

2. Alosco ML, Kasimis AB, Stamm JM, Chua AS, Baugh CM, Daneshvar DH, et al. Age of frst exposure to American football and long-term neuropsychiatric and cognitive outcomes. Transl Psychiatry. 2017;7(9):e1236.

3. Andersen KG, Rambaut A, Lipkin WI, Holmes EC, Garry RF. The proximal origin of SARS-CoV-2", Nature Medicine 2020; 26: 450-455

4. Association of Secondary Teachers of Ireland. (2011). ASTI survey of newly qualified teachers. Dublin, OH: Author.

5. Associations NFoSHS. (2018). 2017-18 high school athletics participation survey. http://www.nfhs.org/ParticipationStatistics/PDF/2017-18\%20High\%20School\% 20Athletics\%20Participation\%20Survey.pdf

6. Barnabe, L., Volossovitch, A., Duarte, R., Ferreira, A., \& Davids, K. (2016). Age-related effects of practice experience on collective behaviours of football players in smallsided games. Human Movement Science, 48, 7481. doi:10.1016/j.humov.2016.04.007

7. Baugh, C. M., Weintraub, G. S., Gregory, A. J., Djoko, A., Dompier, T. P., \& Kerr, Z. Y. (2018). Descriptive epidemiology of injuries sustained in national collegiate athletic association men's and women's volleyball, 20132014 to 2014-2015. Sport Health, 10(1), 60e69.

8. Baugh, C. M., Kroshus, E., Daneshvar, D. H., Filali, N. A., Hiscox, M. J., \& Glantz, L. H. (2014). Concussion Management in United States College Sports. The American Journal of Sports Medicine, 43(1), 4756. doi:10.1177/0363546514553090

9. Bell, D. R., Lang, P. J., McLeod, T. C. V., McCaffrey, K. A., Zaslow, T. L., \& McKay, S. D. (2018). Sport specialization is associated with injury history in youth soccer athletes. Athletic Training \& Sports Health Care, 10(6), $241 e 246$.

10. Binti, Alminnourliza \& Fadhilah, Noordin \& Anuar, Nur Khairiel. (2018). Astin's Theory of Student Involvement. 10.13140/RG.2.2.21801.03687.

11. Biese, K. M., McGuine, T. A., Kliethermes, S. A., Bell, D. R., Post, E. G., Watson, A. M., ... Lang, P. J. (2020). Sport specialization and sport participation opportunities and their association with injury history in female high school volleyball athletes. Physical Therapy in Sport. doi:10.1016/j.ptsp.2020.06.005

12. Booth, F. W. et al. Role of inactivity in chronic diseases: evolutionary insight and pathophysiological mechanisms. Physiol. Rev. 97, 1351-1402 (2017).

13. Bozkus, T., Turkmen, M., \& Kul, M. (2013). The effects of age, sports experience and physical self perception on competition anxiety levels of female football player. International Journal of Academic Research, 5(4), 509513. doi:10.7813/2075-4124.2013/5-4/b.72

14. Bowen, W. G., \& Levin, S. A. (2011). Reclaiming the game: College sports and educational values. Princeton, NJ: Princeton University Press.

15. Bocarro, J. N., Kanters, M. A., Edwards, M. B., Casper, J. M., \& McKenzie, T. L. (2014). Prioritizing school intramural and interscholastic programs based on observed physical activity. American Journal of Health Promotion, 28(Suppl. 3), S65-S71. doi:10.4278/ ajhp.130430-QUAN-25

16. Bourbousson J, Kiouak M, Eccles D. The dynamics of team coordination: A social network analysis as a window to shared awareness. EJWOP. 2015:1-19.

17. British Journal of Educational Psychology, 81, 391-408. doi:10.1348/2044- 8279.002001

18. Brooks SK, Webster RK, Smith LE, et al. The psychological impact of quarantine and how to reduce it: rapid review of the evidence. Lancet 2020;395:912-920

19. Browman, A. S., Destin, M., Carswell, K. L., \& Svoboda, R. C. (2017). Perceptions of socioeconomic mobility influence academic persistence among low socioeconomic status students. Journal of Experimental Social Psychology, 72, 45-52. doi:10.1016/j.jesp.2017.03.006

20. Brown, K. A., Patel, D. R., \& Darmawan, D. (2017). Participation in sports in relation to adolescent growth and development. Translational Pediatrics, 6(3), 150-159. doi:10.21037/tp.2017.04.03

21. Buckels, E. E., Jones, D. N., \& Paulhus, D. L. (2013). Behavioral confirmation of everyday sadism. Psychological Science, 24, 2201-2209

22. Caccese, J. B., DeWolf, R. M., Kaminski, T. W., Broglio, S. P., McAllister, T. W., ... Buckley, T. A. (2019). Estimated Age of First Exposure to American Football and Neurocognitive Performance Amongst NCAA Male Student-Athletes: A Cohort Study. Sports Medicine. doi:10.1007/s40279-019-01069-x

23. Cervantes, C., \& Meaney, K. (2013). Examining service-learning literature in physical education teacher education: Recommendations for practice and research. Quest, 65, 332-354. 


\section{SJIF Impact Factor 2021: 8.013| ISI I.F.Value:1.241| Journal DOI: 10.36713/epra2016 ISSN: 2455-7838(Online) EPRA International Journal of Research and Development (IJRD) Volume: 6 | Issue: 7 | July 2021 \\ - Peer Reviewed Journal}

24. Chambers, J. R., Swan, L. K., \& Heesacker, M. (2015). Perceptions of U.S. social mobility are divided (and distorted) along ideological lines. Psychological Science, 26(4), 413-423 http://doi.org/10.1177/0956797614566657.

25. Chan ALY, Leung CC, Lam TH, Cheng KK. To wear or not to wear: WHO's confusing guidance on masks in the covid-19 pandemic. BMJ opinion 2020. https:// blogs.bmj.com/bmj/2020/03/11/whos-confusing-guidance-maskscovid-19-epidemic/.

26. Chester, D. S., DeWall, C. N., \& Enjaian, B. (2017). Sadism and aggression: Inflicting pain to feel pleasure. Manuscript submitted for publication.

27. Chester, D. S. (2017). The Role of Positive Affect in Aggression. Current Directions in Psychological Science, 26(4), 366-370. doi:10.1177/0963721417700457

28. Chow, J., Davids, K., Button, C., \& Renshaw, I. (2015). Nonlinear pedagogy in skill acquisition: An introduction. New York, NY: Routledge

29. Clarke, M., \& Killeavy, M. (2012). Charting teacher education policy in the Republic of Ireland with particular reference to the impact of economic recession. Educational Research, 54(2), 125-136. doi:10.1080/00131881.2012.680038

30. CIRP (2015). The American freshman: National norms fall 2015. Los Angeles, CA: Higher Education Research Institute, UCLA.

31. Colzato L, Szapora A, Pannekoek JN, Hommel B. The impact of physical exercise on convergent and divergent thinking. Front Hum Neurosci. 2013; 7:824. doi: 10.3389/fnhum.2013.00824 PMID: 24348370

32. Conway, F. N., Domingues, M., Monaco, R., Lesnewich, L. M., Ray, A. E., Alderman, B. L., . . Buckman, J. F. (2018, January). Concussion symptom underreporting among incoming national collegiate athletic association division I college athletes. Clinical Journal of Sport Medicine : Official Journal of the Canadian Academy of Sport Medicine, 1. doi:10.1097/JSM.0000000000000557

33. Coutts AJ. In the age of technology, Occam's razor still apllies. Int J Sports Physiol Perform. 2014;9:741.

34. Coutts AJ. Working fast and working slow: the benefits of embedding research in high-performance sport. Int J Sports Physiol Perform. 2016;11:1-2.

35. Covassin ,Tracey PhD, ATC, FNATA, Department of Kinesiology, Michigan State University, 105 IM Sports Circle, East Lansing, MI 48824 "Exploring the Relationship Between Depression and Seasonal Affective Disorder in Incoming First Year Collegiate Student-Athletes”, Published Online: July 10, 2018https://doi.org/10.3928/19425864-20180710-01

36. Craig, D. I., Lininger, M. R., Wayment, H. A., \& Huffman, A. H. (2019, March). Investigation of strategies to improve concussion reporting in American football. Research in Sports Medicine Print, 1-13. doi:10.1080/15438627.2019.1586706

37. Daly RM, Ducher G, Hill B, et al. Effects of a SpecialistLed, School Physical Education Program on Bone Mass, Structure, and Strength in Primary School Children: A 4-Year Cluster Randomized Controlled Trial. J Bone Miner Res 2016;31:289-98.

38. Derse, E., Hansen, J., O'Rourke, T. and Stolley, S. (2008). Track And Field Coaching Manual.

39. Dombrovskis, V., Guseva, S., \& Capulis, S. (2014). Cooperation and Learning Effectiveness of First Graders During Sports Lessons. Procedia - Social and Behavioral Sciences, 112, 124132. doi:10.1016/j.sbspro.2014.01.1146

40. Eadeh, F. R., Peak, S. A., \& Lambert, A. J. (2017). The bittersweet taste of revenge: On the negative and positive consequences of retaliation. Journal of Experimental Social Psychology, 68, 27-39.

41. Elder, S. (2009), Fundamental Motor Skills, Teacher's Manual http://www.education.vic.gov.au.

42. Ellison, J., \& Partridge, J. A. (2012). Relationships between shame-coping, fear of failure, and perfectionism in college athletes. Journal of Sport Behavior, 35(1), 19-39. doi:10.1046 /j.0022-4537.2003

43. Everhart, K. (2014). Using School-based Intramurals as Early Field Experiences for Physical Education Teacher Education Majors. Journal of Physical Education, Recreation \& Dance, 85(9), 4446. doi:10.1080/07303084.2014.958032

44. Faude $O$, Koch T, Meyer T. Straight sprinting is the most frequent action in goal situations in professional football. J Sport Sci. 2012; 30(7):625-3

45. Ferguson $N$, Laydon D, Nedjati-Gilani $G$, Imai $N$, Ainslie $K$, Baguelin $M$, et al. Report 9-Impact of nonpharmaceutical interventions (NPIS) to reduce COVID-19 mortality And healthcare demand. Imperial College London; 2020.

46. Folgado, H., Lemmink, K., Frencken, W., \& Sampaio, J. (2014). Length, width and centroid distance as measures of teams tactical performance in youth football. European Journal of Sport Science, 14(Suppl. 1), S487-S492. doi:10.1080/17461391.2012.730060 


\section{SJIF Impact Factor 2021: 8.013| ISI I.F.Value:1.241| Journal DOI: 10.36713/epra2016 ～ISSN: 2455-7838(Online) EPRA International Journal of Research and Development (IJRD) Volume: 6 | Issue: 7 | July 2021 - Peer Reviewed Journal}

47. Garn, A. C., McCaughtery, N., Kulik, N., Kaseta, M., Maljak, K., Whalen, L., ... Fahlman, M. (2014). Successful after-school physical activity clubs in urban high schools: Perspectives of adult leaders and student participants. Journal of Teaching in Physical Education, 33, 112-133

48. Gaudelli, W. (2016). Global citizenship education: Everyday transcendence. New York, NY: Routledge

49. Gayles, J. G., \& Baker, A. R. (2015). Opportunities and Challenges for First-Year Student-Athletes Transitioning From High School to College. New Directions for Student Leadership, 2015(147), 43-51. doi:10.1002/yd.20142

50. Glickman, M. E., \& Sonas, J. (2015). Introduction to the NCAA men's basketball prediction methods issue. Journal of Quantitative Analysis in Sports, 11(1), 1-3. doi:10.1515/jqas-2015-0013

51. Goldschmied, N., \& Kowalczyk, J. (2014). Gender Performance in the NCAA Rifle Championships: Where is the Gap? Sex Roles, 74(7-8), 310-322. doi:10.1007/s11199-014-0436-y

52. Goren, H., \& Yemini, M. (2017). The global citizenship education gap: Teacher perceptions of the relationship between global citizenship education and students' socio-economic status. Teaching and Teacher Education, 67, 9-22. doi:10.1016/j.tate.2017.05.009

53. Greenhalgh T, Schmid MB, Czypionka T, Bassler D, Gruer L. Face masks for the public during the covid-19 crisis. BMJ 2020;369:m1435.

54. Hale M. Nutritional habits \& knowledge in the division I collegiate football player. Report thesis. Utah State University, Health, Physical Education, and Recreation. All Graduate Plan B and other Reports; 2013.

55. Halson SL. Monitoring training load to understand fatigue in athletes. Sports Med. 2014;44 (Suppl. 2):S139-S147.

56. Heinz, M. (2013). Why choose teaching in the Republic of Ireland? - Student teachers' motivations and perceptions of teaching as a career and their evaluations of Irish second - Level education. European Journal of Educational Studies, 5(1), 1-17.

57. Henz D, Scho"llhorn WI. Differential training facilitates early consolidation in motor learning. Front Behav Neurosci. 2016; 10:199. doi: 10.3389/fnbeh.2016.00199 PMID: 27818627

58. Henz, D., \& Schöllhorn, W. (2016). Differential training facilitates early consolidation in motor learning. Frontiers in Behavioral Neuroscience, 10, 199. doi:10.3389/ fnbeh.2016.00199

59. Hennessy, J., \& Lynch, R. (2016). "I chose to become a teacher because". Exploring the factors influencing teaching choice amongst pre-service teachers in Ireland. Asia-Pacific Journal of Teacher Education, 45(2), 106125. doi:10.1080/1359866x.2016.1183188

60. Hristovski, R., Davids, K., Passos, P., \& Araujo, D. (2012). Sport performance as a domain of creative problem solving for self-organizing performer-environment systems. The Open Sports Science Journal, 5, $26-35$. doi:10.2174/ 1875399X01205010026

61. Holodov, Zh. K., \& Kuznetsov, V.S. (2011). Teoriya i methodika phizicheskogo vospitaniya i sporta [Theory and Methodology of Physical

62. Huang C, Wang Y, Li X, Ren L, Zhao J, Hu Y, et al. Clinical features of patients infected with 2019 novel coronavirus in Wuhan, China. Lancet. 2020;395:497-506. doi:10.1016/S0140-6736(20)30183-5.

63. Hull, M. V., Jagim, A. R., Oliver, J. M., Greenwood, M., Busteed, D. R., \& Jones, M. T. (2016). Gender differences and access to a sports dietitian influence dietary habits of collegiate athletes. Journal of the International Society of Sports Nutrition, 13(1). doi:10.1186/s12970-016-0149-4

64. Ishihara, T., Sugasawa, S., Matsuda, Y., \& Mizuno, M. (2017). Relationship between sports experience and executive function in 6-12-year-old children: independence from physical fitness and moderation by gender. Developmental Science, 21(3), e12555. doi:10.1111/desc.12555

65. Jayanthi, N. A., \& Dugas, L. R. (2017). The risks of sports specialization in the adolescent female athlete. Strength and Conditioning Journal, 39(2), $20 e 26$.

66. Jayanthi, N. A., LaBella, C. R., Fischer, D., Pasulka, J., \& Dugas, L. R. (2015). Sportsspecialized intensive training and the risk of injury in young athletes: A clinical case-control study. The American Journal of Sports Medicine, 43(4), 794e801.

67. Jost, K., De Baene, W., Koch, I., \& Brass, M. (2013). A review of the role of cue processing in task switching. Zeitschrift für Psychologie, 221, 5-14.

68. Jury, M., Smeding, A., Stephens, N. M., Nelson, J. E., Aelenei, C., \& Darnon, C. (2017). The experience of lowSES students in higher education: Psychological barriers to success and interventions to reduce social-class inequality. Journal of Social Issues, 73(1), 16-34 http://doi.org/10.1111/josi.12202.

69. Kelly KC, Jordan EM, Joyner AB, Burdette GT, Buckley TA. National collegiate athletic association division I athletic trainers' concussion-management practice patterns. J Ath Train. 2014;49(5):665-73.

70. Kerr, Z. Y., Gregory, A. J., Wosmek, J., et al. (2018). The first decade of web-based sports injury surveillance: Descriptive epidemiology of injuries in US high school girls' volleyball (2005-2006 through 2013-2014) and national collegiate athletic association women's volleyball (2004-2005 through 2013-2014). Journal of Athletic Training, 53(10), 926e937. 


\section{SJIF Impact Factor 2021: 8.013| ISI I.F.Value:1.241| Journal DOI: 10.36713/epra2016 ～ISSN: 2455-7838(Online) EPRA International Journal of Research and Development (IJRD) Volume: 6 | Issue: 7 | July 2021 \\ - Peer Reviewed Journal}

71. Koh, W. C., Naing, L., \& Wong, J. (2020). Estimating the impact of physical distancing measures in containing COVID-19: an empirical analysis. International Journal of Infectious Diseases. doi:10.1016/j.ijid.2020.08.026

72. Lai SK, Costigan S, Morgan P, Lubans D, Stodden D, Salmon J, et al. Do school-based interventions focusing on physical activity, fitness, or fundamental movement skill competency produce a sustained impact in these outcomes in children and adolescents? A systematic review of follow-up studies. Sports Med. 2014; 44(1):67-79. doi: 10.1007/s40279-013-0099-9 PMID: 24122775

73. Lambert MI, Mujika I. Physiology of exercise training. In: Hausswirth C, Mujika I eds. Recovery for Performance in Sport. Champaign, IL: Human Kinetics; 2013:3-8.

74. Lambert MI. Quantification of endurance training and competition loads. In: Mujika I, ed. Endurance Training. Science and Practice. Vitoria-Gasteiz, Basque Country: Iñigo Mujika S.L.U.;2012:211-228.

75. López, R. L., \& Levy, J. J. (2013). Student Athletes' Perceived Barriers to and Preferences for Seeking Counseling. Journal of College Counseling, 16(1), 19-31. doi:10.1002/j.2161-1882.2013.00024.x

76. Lupo, C., Mosso, C. O., Guidotti, F., Cugliari, G., Pizzigalli, L., \& Rainoldi, A. (2016). Motivation toward dual career of Italian student-athletes enrolled in different university paths. Sport Sciences for Health, 13(3), 485494. doi:10.1007/s11332-016-0327-4

77. Maloney W, Taskin T. Determinants of social distancing and economic activity during COVID-19: a global view. CEPR Covid Econ 2020;13:157-77

78. Marchetti, R., Forte, R., Borzacchini, M., Vazou, S., Tomporowski, P.D., \& Pesce, C. (2015). Physical and motor fitness, sport skills and executive function in adolescents: A moderated prediction model. Psychology, 6, 19151929.

79. McGuine, T. A., Post, E. G., Hetzel, S. J., Brooks, M. A., Trigsted, S., \& Bell, D. R. (2017). A prospective study on the effect of sport specialization on lower extremity injury rates in high school athletes. The American Journal of Sports Medicine, 45(12), 2706e2712, 363546517710213.

80. Medicine: Nutrition and athletic performance. J Acad Nutr Diet. 2016;116:501-28.

81. Mihalik, J. K., Marshall, S. W., Kay, M. C., Kerr, Z. Y., Peck, K. Y., Houston, M. N., ... Cameron, K. L. (2020). Perceived social norms and concussion-disclosure behaviours among first-year NCAA student-athletes: implications for concussion prevention and education. Research in Sports Medicine, 111. doi:10.1080/15438627.2020.1719493

82. Miller, J.J. (2011). Impact of a university recreation center on social belonging and student retention. Recreational Sports Journal, 35(2), 117-129.

83. Miller, M. (2012). The role of service-learning to promote early childhood physical education while examining its influence upon the vocational call to teach. Physical Education and Sport Pedagogy, 17, 61-77

84. Montenigro PH, Alosco ML, Martin BM, Daneshvar DH, Mez J, Chaisson CE, et al. Cumulative head impact exposure predicts later-life depression, apathy, executive dysfunction, and cognitive impairment in former high school and college football players. J Neurotrauma. 2017;34(2):328-40.

85. Moy B, Renshaw I, Davids K. The impact of nonlinear pedagogy on physical education teacher education students' intrinsic motivation. Phys Educ Sport Pedagog. 2015:1-22.

86. Mujika, I. (2017). Quantification of Training and Competition Loads in Endurance Sports: Methods and Applications. International Journal of Sports Physiology and Performance, 12(Suppl 2), S2-9-S2-17. doi:10.1123/ijspp.2016-0403

87. Mujika I. The alphabet of sports science research starts with Q. Int J Sports Physiol Perform. 2013;8:465-466.

88. Mushi, V., Shao, M. Tailoring of the ongoing water, sanitation and hygiene interventions for prevention and control of COVID-19. Trop Med Health 48, 47 (2020). https://doi.org/10.1186/s41182-020-00236-5

89. Myers, J. P. (2016). Charting a democratic course for global citizenship education: Research directions and current challenges. Education Policy Analysis Archives, 24, 1e15

90. NCAA. (2013). Probability of competing beyond high school. Indianapolis, IN: The National Collegiate Athletic Association. Retrieved from http://www.ncaa.org/about /resources/research/probability-competing-beyond-highschool

91. NCAA. (2014a). 2013-2014 Division I manual. Indianapolis, IN: The National Collegiate Athletic Association. Retrieved from http://www.ncaapublications.com /productdownloads/D114.pdf

92. NCAA (2014b). 2013-2014 guide for the college-bound student-athlete. Indianapolis, IN: The National Collegiate Athletic Association. Retrieved from http://www .ncaapublications.com/productdownloads/CBSA.pdf

93. Neal, T. L., Diamond, A. B., Goldman, S., Liedtka, K. D., Mathis, K., Morse, E. D., ... Welzant, V. (2015). Interassociation Recommendations for Developing a Plan to Recognize and Refer Student-Athletes With Psychological Concerns at the Secondary School Level: A Consensus Statement. Journal of Athletic Training, 50(3), 231-249. doi:10.4085/1062-6050-50.3.03

94. Nieman DC (2020) Coronavirus disease-2019: a tocsin to our aging, unfit, corpulent, and immunodeficient society. J Sport Heal Sci. https://doi.org/10.1016/j.jshs.2020.05.001 


\section{SJIF Impact Factor 2021: 8.013| ISI I.F.Value:1.241| Journal DOI: 10.36713/epra2016 ～ISSN: 2455-7838(Online) EPRA International Journal of Research and Development (IJRD) Volume: 6 | Issue: 7 | July 2021 - Peer Reviewed Journal}

95. Oyserman, D. (2013). Not just any path: Implications of identity-based motivation for disparities in school outcomes. Economics of Education Review, 33, 179-190 http:// doi.org/10.1016/j.econedurev.2012.09.002.

96. 'Oyserman, D., Destin, M., \& Novin, S. (2015). The context-sensitive future self: Possible selves motivate in context, not otherwise. Self and Identity, 14(2), 173-188. http:// doi.org/http://dx.doi.org/10.1080/15298868.2014.965733.

97. Oxley, L., \& Morris, P. (2013). Global citizenship: A typology for distinguishing its multiple conceptions. British Journal of Educational Studies, 61, 301e325.

98. Palmowski J, Boßlau TK, Ryl L et al (2019) Managing immune health in sports - a practical guide for athletes and coaches. Dtsch Z Sportmed 70:219-226. https://doi.org/10.5960/dzsm.2019.389

99. Panday, P.K. and Jamil, I., 2011. Challenges of coordination in implementing urban policy: the Bangladesh experience. Public organization review, 11, 155-176. doi:10.1007/s11115-010-0116-5

100. Pew Research Center (2012). Young, underemployed and optimistic: Coming of age, slowly, in a tough economy (social \& demographic trends). Washington, D.C.: Pew Research Center.

101. 90. Pindus, D.M., Drollette, E.S., Scudder, M.R., Khan, N.A., Raine, L.B., Sherar, L.B., ... \& Hillman, C.H. (2016). Moderate-to-vigorous physical activity, indices of cognitive control, and academic achievement in preadolescents. Journal of Pediatrics, 173, 136-142

102. 91. Runco M. Creativity: Theories and themes: Research, development, and practice: Elsevier Science; 2014.

103. Runco M, Acar S. Divergent thinking as an indicator of creative potential. Creat Res J. 2012; 24(1):66- 75.

104. Stamm JM, Koerte IK, Muehlmann M, Pasternak O, Bourlas AP, Baugh CM, et al. Age at frst exposure to football is associated with altered corpus callosum white matter microstructure in former professional football players. $J$ Neurotrauma. 2015;32(22):1768-76.

105. Schultz V, Stern RA, Tripodis Y, Stamm JM, Wrobel P, Lepage C, et al. Age at frst exposure to repetitive head impacts is associated with smaller thalamic volumes in former professional American football players. $J$ Neurotrauma. 2017;35(2):278-85.

106. Santos, S., Memmert, D., Sampaio, J., \& Leite, N. (2016). The spawns of creative behavior in team sports: A creativity developmental framework. Frontiers in Psychology, 7, 1282. doi:10.3389/fpsyg.2016.01282

107. Santos, S., Coutinho, D., Gonçalves, B., Schöllhorn, W., Sampaio, J., \& Leite, N. (2018). Differential Learning as a Key Training Approach to Improve Creative and Tactical Behavior in Soccer. Research Quarterly for Exercise and Sport, 89(1), 11-24. doi:10.1080/02701367.2017.1412063

108. Santos, S., Jiménez, S., Sampaio, J., \& Leite, N. (2017). Effects of the Skills4Genius sports-based training program in creative behavior. PLOS ONE, 12(2), e0172520. doi:10.1371/journal.pone.0172520

109. Santos S, Memmert D, Sampaio J, Leite N. The spawns of creative behavior in team sports: A creativity developmental framework. Front Psychol. 2016; 7:1282. doi: 10.3389/fpsyg.2016.01282 PMID: 27617000

110. Saw AE, Main LC, Gastin PB. Monitoring the athlete training response: subjective self-reported measures trump commonly used objective measures: a systematic review. Br J Sports Med. 2016;50:281-291.

111. Sagar, S., \& Jowet, S. (2012). The effects of age, gender, sport type and sport level on athletes' fear of failure: Implications and recommendations for sport coaches. International Journal of Coaching Science, 2, 61-82.

112. Sagar, S. S., Boardley, I. D., \& Kavussanu, M. (2011). Fear of failure and student athlete's interpersonal antisocial behaviour in education and sport.

113. Schneider, D. W. (2015). Attentional control of response selection in task switching. Journal of Experimental Psychology: Human Perception and Performance, 41(5), 1315-1324.

114. Siddharta A, Pfaender S, Vielle NJ, Dijkman R, Friesland M, Becker B, et al. Virucidal activity of World Health Organization-recommended formulations against enveloped viruses, including Zika, Ebola, and emerging coronaviruses. J Infect Dis. 2017;215(6):902-6. doi:10.1093/infdis/jix046.

115. Silvia, J. E., Quinlan, T., \& Seydl, J. (2011). Economic mobility: Is "rags to riches" still possible? Wells Fargo Securities Economics Group

116. Shulman, J. L., \& Bowen, W. G. (2011). The game of life: College sports and educational values. Princeton, NJ: Princeton University Press.

117. Shoaib, M. and Ullah, H. (2021), "Teachers' perspectives on factors of female students' outperformance and male students' underperformance in higher education", International Journal of Educational Management, Vol. aheadof-print No. ahead-of-print. https://doi.org/10.1108/IJEM-05-2020-0261

118. Smith PJ, Blumenthal JA, Hofman BM, Cooper H, Strauman TA, Welsh-Bohmer K, et al. Aerobic exercise and neurocognitive performance: a meta-analytic review of randomized controlled trials. Psychosom Med. 2012;72(3):239-52.

119. Sorenson, S. C., Romano, R., Scholefield, R. M., Martin, B. E., Gordon, J. E., Azen, S. P., ... Salem, G. J. (2014). Holistic Life-Span Health Outcomes Among Elite Intercollegiate Student-Athletes. Journal of Athletic Training, 49(5), 684-695. doi:10.4085/1062-6050-49.3.18 


\section{SJIF Impact Factor 2021: 8.013| ISI I.F.Value:1.241| Journal DOI: 10.36713/epra2016 ～ISSN: 2455-7838(Online) EPRA International Journal of Research and Development (IJRD) Volume: 6 | Issue: 7 | July 2021 \\ - Peer Reviewed Journal}

120. Stamm JM, Bourlas AP, Baugh CM, Fritts NG, Daneshvar DH, Martin BM, et al. Age of frst exposure to football and laterlife cognitive impairment in former NFL players. Neurology. 2015;84(11):1114-20.

121. 110

122. Steinfeldt, J. A., Carter, H., Benton, E., \& Steinfeldt, M. C. (2011). Muscularity Beliefs of Female College StudentAthletes. Sex Roles, 64(7-8), 543-554. doi:10.1007/s11199-011-9935-2

123. Strobach, T., Wendt, M., Tomat, M., Luna-Rodriguez, A., \& Jacobsen, T. (2020). No evidence for the reduction of task competition and attentional adjustment during task-switching practice. Acta Psychologica, 204, 103036. doi:10.1016/j.actpsy.2020.103036

124. Skre I, Friborg O, Breivik C, Johnsen LI, Arnesen Y, Wang CE. A school intervention for mental health literacy in adolescents: effects of a non-randomized cluster controlled trial. BMC Public Health. 2013;13:873.

125. Scho"llhorn W, Hegen P, Davids K. The nonlinear nature of learning-A differential learning approach. TOSSJ. 2012; 5:100-12.

126. Sposato W. Japan's Halfhearted Coronavirus Measures Are Working Anyway. Foreign Policy. May 14. 2020. https://foreignpolicy.com/2020/05/14/japancoronavirus-pandemic-lockdown-testing/.

127. Sturts, Jill R \& Ross Craig M. (2013). “Collegiate Intramural Sports Participation: Identified Social Outcomes”. International Journal Sport Management Recreation \& Tourism. Department Recreation, Park and Tourism, Indiana University, Bloomington, IN 474505. International Journal of Sport Management Recreation \& Tourism, Vol.11, p.25-41, 2013 (C) 2013 I.J.S.Ma.R.T. All rights reserved. ISSN: 1791-874X To link to this article: http://dx.doi.org/DOI: 10.5199/ijsmart-1791-874X-11b

128. Torres-McGehee TM, Pritchett KL, Zippel D, Minton DM, Cellamare A, Sibilia M. Sports nutrition knowledge among collegiate athletes, coaches, athletic trainers, and strength and conditioning specialists. J Athl Train. 2012;47:205-11.

129. Thomas DT, Erdman KA, Burke LM. Position of the Academy of Nutrition and Dietetics, Dietitians of Canada, and the American College of Sports

130. Uematsu A, Matsui M, Tanaka C, Takahashi T, Noguchi K, Suzuki M, et al. Developmental trajectories of amygdala and hippocampus from infancy to early adulthood in healthy individuals. PLoS One. 2012;7(10):e46970.

131. USA Shooting. (2012, February 28). USA Shooting viewpoint: men vs. women in competitive shooting. Retrieved from http://www. usashooting.org/news/2012/2/28/195-usa-shooting-viewpoint- men-vs-women-in-competitiveshooting.

132. Valliant MW, Emplaincourt HP, Wenzel RK, Garner BH. Nutrition education by a registered dietitian improves dietary intake and nutrition knowledge of a NCAA female volleyball team. Nutrients. 2012;4:506-16.

133. Vandegrift R, Bateman AC, Siemens KN, Nguyen M, Wilson HE, Green JL, et al. Cleanliness in context: reconciling hygiene with a modern microbial perspective. Microbiome 2017; 5: 76.

134. Vos, S., Vandermeerschen, H., \& Scheerder, J. (2016). Balancing between coordination, cooperation and competition? A mixed-method approach for assessing the role ambiguity of local sports authorities. International Journal of Sport Policy and Politics, 8(3), 403-419. doi:10.1080/19406940.2015.1123756

135. Vos, S. and Scheerder, J., 2014. Fact or fiction? An empirical analysis of co-operation between mass sport providers at the local level. European journal for sport and society, 11 (1), 7-34.

136. Watt, H. M., Richardson, P. W., Klusmann, U., Kunter, M., Beyer, B., Trautwein, U., \& Baumert, J. (2012). Motivations for choosing teaching as a career: An international comparison using the FIT-choice scale. Teaching and Teacher Education, 28(6), 791-805. doi:10.1016/j.tate.2012.03.003

137. Weeden AM, Olsen J, Batacan JM, Peterson T. Differences in collegiate athlete nutrition knowledge as determined by athlete characteristics. Sport J. 2014;12.

138. World Health Organization and the United Nations Children's Fund (UNICEF), 2020. Some rights reserved. This work is available under the CC BY-NC-SA 3.0 IGO 